\title{
Reductive chain separation of botulinum A toxin - a prerequisite to its inhibitory action on exocytosis in chromaffin cells
}

\author{
B. Stecher, M. Gratzl and G. Ahnert-Hilger \\ Abteilung Anatomie und Zellbiologie der Universität Ulm, D-7900 Ulm, FRG
}

Received 8 March 1989

\begin{abstract}
Cleavage of the disulfide bond linking the heavy and the light chains of tetanus toxin is necessary for its inhibitory action on exocytotic release of catecholamines from permeabilized chromaffin cells [(1989) FEBS Lett. 242, 245-248; (1989) J. Neurochem., in press]. The related botulinum A toxin also consists of a heavy and a light chain linked by a disulfide bond. The actions of both neurotoxins on exocytosis were presently compared using streptolysin O-permeabilized bovine adrenal chromaffin cells. Botulinum $\mathrm{A}$ toxin inhibited $\mathrm{Ca}^{2+}$-stimulated catecholamine release from these cells. Addition of dithiothreitol lowered the effective doses to values below $5 \mathrm{nM}$. Under the same conditions, the effective doses of tetanus toxin were decreased by a factor of five. This indicates that the interchain $\mathrm{S}-\mathrm{S}$ bond of botulinum $\mathrm{A}$ toxin must also be split before the neurotoxin can exert its effect on exocytosis.
\end{abstract}

Botulinum A toxin; Chain separation; Reduction; Exocytosis; (Chromaffin cell)

\section{INTRODUCTION}

The clostridial neurotoxins tetanus toxin (Tetx) and botulinum toxin A (Botx A) are members of a family of closely related high molecular mass proteins. The $150 \mathrm{kDa}$ proteins consist of a heavy and a light chain covalently linked by a disulfide bond. They belong to the most poisonous substances known. Their main target is the central (Tetx) or the peripheral (Botx A) nervous system where they act as very potent inhibitors of transmitter release [3-5]. Besides their well-known effects on neurons, Tetx and Botx $A$ have recently been reported to inhibit exocytosis from adrenal

Correspondence address: G. Ahnert-Hilger, Abteilung Anatomie und Zellbiologie, Universität Ulm, Postfach 4066, D-7900 Ulm, FRG

Abbreviations: Pipes, 1,4-piperazinediethanesulfonic acid; KG buffer, potassium glutamate buffer; Botx A (B), botulinum A (B) toxin; Tetx, tetanus toxin; SLO, streptolysin O; DTT, dithiothreitol; NTA, nitriloacetic acid; DMEM, Dulbecco's modified Eagle's medium medullary chromaffin cells when injected intracellularly [6]. Similar results were obtained when chromaffin cells were treated extracellularly with large amounts of various botulinum neurotoxins, whereas Tetx was ineffective under these conditions [7].

Using permeabilized chromaffin cells, the intracellular effects on exocytosis by these neurotoxins can be studied more directly. In such preparations the internalization process is bypassed and defined doses can be applied. Recently, the inhibitory action of Tetx on exocytosis from digitonin- [8] and streptolysin $\mathrm{O}$ (SLO)permeabilized chromaffin cells has been described $[1,2]$. Furthermore, the effect of Tetx can be augmented by addition of dithiothreitol (DTT), which reduces the interchain disulfide bond between the heavy and light chains of Tetx $[1,2]$. Even the purified light chain alone has been found to inhibit exocytosis [1]. The present study was undertaken to determine whether Botx A requires activation via a similar process to that for Tetx before becoming effective within the cell. 


\section{EXPERIMENTAL}

\subsection{Materials}

Tetx, Botx A and Botx B were a generous gift from U. Weller and E. Habermann (Rudolf Buchheim-Institut für Pharmakologie, Giessen, FRG). The $\mathrm{LD}_{50}$ in mice was $2 \mathrm{ng} / \mathrm{kg}$ for Tetx, and $3 \mathrm{ng} / \mathrm{kg}$ for both botulinum toxins. Streptolysin $O$ was kindly provided by S. Bhakdi (Institut für Mikrobiologie, Giessen). Botx A antitoxin (horse, $750 \mathrm{IU} / \mathrm{ml}$ ) was obtained from Behring Werke (Marburg), collagenase $(0.7 \mathrm{IU} / \mathrm{mg}$ ) from Serva (Heidelberg), collagen (rat tail) and cytosine arabinoside from Sigma (München), and DMEM and fetal calf serum from Seromed, Biochrom KG (Berlin, Germany).

\subsection{Cell cultures}

Chromaffin cells from bovine adrenal medulla were prepared as described [9]. Briefly, fresh adrenals were dissected free of fat and connective tissue and immediately rinsed free of blood by several retrograde injections of ice-cold buffer I (mM: 150 $\mathrm{NaCl}, 5 \mathrm{KCl}, 10$ glucose, 10 Hepes, pH 7.4, supplemented with $50 \mathrm{IU}$ penicillin, $50 \mu \mathrm{g} / \mathrm{ml}$ streptomycin and $0.25 \mu \mathrm{g} / \mathrm{ml}$ fungizone). The adrenals were transported to the laboratory on ice. The majority of red blood cells were removed by further perfusion as described above. Subsequently, whole glands were incubated with collagenase $(0.05 \%$ in buffer I supplemented with $0.5 \% \mathrm{BSA}$ ) for $1 \mathrm{~h}$ at $37^{\circ} \mathrm{C}$. The medullae were removed and incubated with collagenase for a further $1 \mathrm{~h}$. The resulting cell suspension was filtered through a nylon mesh $(250 \mu \mathrm{m})$ and washed several times with buffer I containing $2 \%$ BSA. The cells were suspended in culture medium (DMEM) containing $10 \%$ fetal calf serum and $5 \mu \mathrm{M}$ cytosine arabinoside. They were plated on precoated (rat tail collagen, $20 \mu \mathrm{g} / \mathrm{ml}$ ) wells at a density of $3 \times 10^{5}$ cells.

Rat pheochromocytoma cells (PC12) kindly provided by $\mathrm{H}$. Thoenen (Max-Planck-Institut für Psychiatrie, Martinsried) were cultivated as stated earlier [10].

\subsection{Assay for exocytosis}

Adrenal chromaffin or PC12 cells were preloaded with tritiated noradrenaline or dopamine $[1,2,10,11]$. After several washes with $\mathrm{Ca}^{2+}$-free buffer II (mM: $140 \mathrm{NaCl}, 4.6 \mathrm{KCl}, 1.2$ $\mathrm{KH}_{2} \mathrm{PO}_{4}, 1.2 \mathrm{MgSO}_{4}, 0.5$ ascorbic acid, 15 Pipes, pH 7.2), buffer III (mM: $150 \mathrm{NaCl}, 10$ Pipes, 1 EGTA, pH 7.2) and KG buffer (mM: $150 \mathrm{~K}^{+}$glutamate, 10 Pipes, 0.5 EGTA, 5 NTA, pH 7.2), cells were permeabilized with SLO $(30 \mathrm{HU} / \mathrm{ml}$ for adrenal chromaffin cells or $60 \mathrm{HU} / \mathrm{ml}$ for PC12 cells) in KG buffer supplemented with $0.1 \% \mathrm{BSA}, 2 \mathrm{mM} \mathrm{M} \mathrm{g}^{2+} / \mathrm{ATP}$ and $1 \mathrm{mM} \mathrm{Mg}^{2+}$ free, either on ice $(\mathrm{PC12})$ or at $37^{\circ} \mathrm{C}$ for $2 \mathrm{~min}[2,11]$. The buffer was then replaced with a fresh one containing the neurotoxin preparations to be tested. After incubation for $25 \mathrm{~min}$ at $37^{\circ} \mathrm{C}$, cells were challenged for $10 \mathrm{~min}$ with $\mathrm{KG}$ buffer containing the indicated amounts of free $\mathrm{Ca}^{2+}$. The buffer was either completely replaced by fresh buffer containing the indicated amounts of free $\mathrm{Ca}^{2+}$ (adrenal chromaffin cells) or $\mathrm{Ca}^{2+}$ was added to obtain the final free $\mathrm{Ca}^{2+}$ concentration ( $\mathrm{PCl} 2$ cells). The $\left[{ }^{3} \mathrm{H}\right]$ catecholamines released were estimated in the supernatant and in cells after lysis in $0.2 \%$ SDS $[1,2,10]$. Values (mean of duplicate or triplicate determinations) are expressed as $\%$ of the radioactivity present at the beginning of stimulation. Free $\mathrm{Ca}^{2+}$ concentrations were calculated using the stability con- stants given in [12] and were routinely monitored by a $\mathrm{Ca}^{2+}$-sensitive electrode [13].

\section{RESULTS}

Adrenal chromaffin cells take up 3-5\% of the radioactive dopamine or noradrenaline offered. When permeabilized with SLO and incubated for $25 \mathrm{~min}$ at $37^{\circ} \mathrm{C}$, equal amounts $(5 \%)$ of $\left[{ }^{3} \mathrm{H}\right]$ noradrenaline or $\left[{ }^{3} \mathrm{H}\right]$ dopamine can be released by micromolar concentrations of free $\mathrm{Ca}^{2+}$ (fig.1). Incubation of permeabilized cells with Botx A for $25 \mathrm{~min}$ at $37^{\circ} \mathrm{C}$ reduces both $\left[{ }^{3} \mathrm{H}\right]$ noradrenaline and $\left[{ }^{3} \mathrm{H}\right]$ dopamine release evoked by $30 \mu \mathrm{M}$ free $\mathrm{Ca}^{2+}$ (fig.1). The effects of Botx A are specific because they can be overcome by boiling or preincubating the toxin with antitoxin. The antitoxin itself has no effect on $\mathrm{Ca}^{2+}$-stimulated release (fig. 1 ).
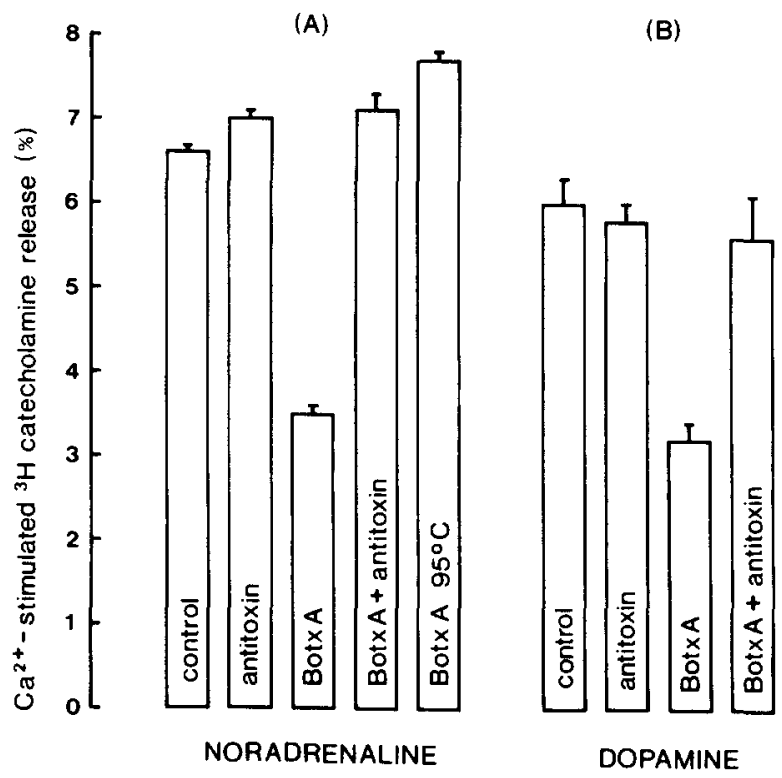

Fig.1. Inhibitory effect of Botx $\mathrm{A}$ on $\mathrm{Ca}^{2+}$-stimulated $\left[{ }^{3} \mathrm{H}\right]$ catecholamine release from SLO-permeabilized adrenal chromaffin cells. Adrenal chromaffin cells were preloaded with either $\left[{ }^{3} \mathrm{H}\right]$ noradrenaline (A) or $\left[{ }^{3} \mathrm{H}\right]$ dopamine (B) and permeabilized with SLO as given in section 2 . The cells were incubated for $25 \mathrm{~min}$ at $37^{\circ} \mathrm{C}$ with antitoxin $(7.5 \mathrm{U} / \mathrm{ml})$, Botx A (4.2 nM), Botx A (4.2 nM) + antitoxin $(7.5 \mathrm{U} / \mathrm{ml})$ or Botx A $(4.2 \mathrm{nM})$ previously heated for $15 \mathrm{~min}$ to $95^{\circ} \mathrm{C}$ as indicated. Before use all toxin dilutions were incubated for $2 \mathrm{~h}$ at room temperature which is necessary for the inactivation of Botx A in the antitoxin-containing sample. The incubation buffer was exchanged for fresh one containing $30 \mu \mathrm{M}$ free $\mathrm{Ca}^{2+}$. Values obtained in two separate experiments are means of three samples \pm SD. 
The inhibitory action of Botx $\mathrm{A}$ increases with incubation time. More than $10 \mathrm{~min}$ are required to affect $\mathrm{Ca}^{2+}$-induced exocytosis (not shown).

Fig. 2 gives a dose-response curve for the inhibitory action of Botx $A$ on exocytosis in the presence or absence of DTT. Although DTT is not absolutely required for the effects of Botx $A$, it drastically reduces the effective dose of this neurotoxin to values below $5 \mathrm{nM}$ final concentration (fig.2). Inhibition by Botx $\mathrm{A}$, even at doses up to $100 \mathrm{nM}$ and in the presence of DTT, is never complete and does not exceed 60-70\% (not shown). Varying the free $\mathrm{Ca}^{2+}$ concentration during stimulation does not substantially alter the inhibition by Botx A (not shown).

Parallel experiments have been performed with Tetx. Again the presence of DTT greatly reduces the effective dose of this neurotoxin (fig.3). However, compared to Botx A, greater amounts of Tetx are required to affect exocytosis (figs 2,3). The complete inhibition observed with Tetx contrasts with the partial inhibition obtained with Botx A under the same conditions (see figs 2,3).

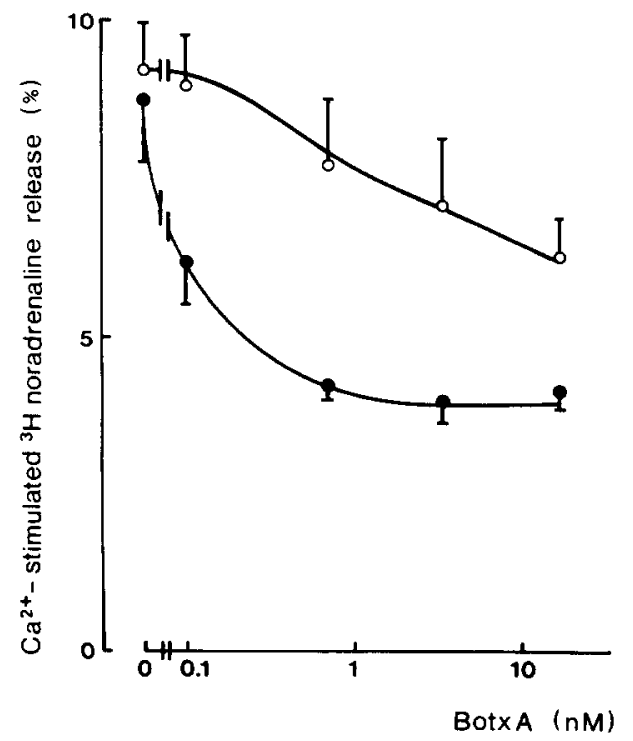

Fig.2. DTT increases the inhibitory effect of Botx $A$ on exocytosis from SLO-permeabilized adrenal chromaffin cells. $\left[{ }^{3} \mathrm{H}\right]$ Noradrenaline-preloaded and SLO-permeabilized adrenal chromaffin cells were incubated with various amounts of Botx A toxin (abscissa) in either the absence $\left(\mathrm{O}^{-} \mathrm{O}\right)$ or presence $(\bullet)$ of $1 \mathrm{mM}$ DTT. Ordinate: $\left[{ }^{3} \mathrm{H}\right]$ noradrenaline released due to stimulation with $30 \mu \mathrm{M}$ free $\mathrm{Ca}^{2+}$. Release in the absence of $\mathrm{Ca}^{2+}$ was approx. $4 \%$ under both conditions. Values are means of three determinations $\pm S D$.

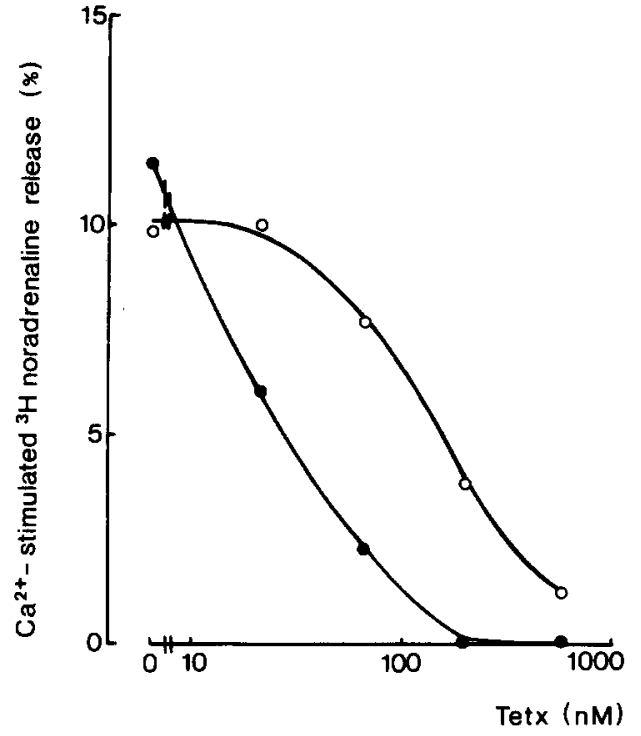

Fig.3. DTT increases the inhibitory effect of Tetx on exocytosis from SLO-permeabilized adrenal chromaffin cells. The procedure followed that given in fig.2. After incubation of cells with the given (abscissa) amounts of Tetx in either the absence $(\mathrm{O}-\mathrm{O})$ or presence $(\bullet)$ of $1 \mathrm{mM}$ DTT, cells were stimulated with $35 \mu \mathrm{M}$ free $\mathrm{Ca}^{2+}$. Values are means of two determinations. Release in the absence of $\mathrm{Ca}^{2+}(4.8 \%)$ was subtracted.

Experiments have been also performed with SLO-permeabilized PC12 cells. These cells exhibit roughly the same sensitivity towards Tetx as adrenal medullary chromaffin cells $[1,2]$. However, catecholamine release from $\mathrm{PC} 12$ as opposed to chromaffin cells is only affected by 20-times higher concentrations of Botx A even when DTT is present (table 1, cf. fig.2).

Table 1

Inhibitory effect of Botx $\mathrm{A}$ on $\mathrm{Ca}^{2+}$-stimulated $\left[{ }^{3} \mathrm{H}\right]$ dopamine release from SLO-permeabilized $\mathrm{PC1} 2$ cells

\begin{tabular}{cc}
\hline & $\begin{array}{c}{\left[{ }^{3} \mathrm{H}\right] \text { Dopamine release }(\%)} \\
\text { stimulated by } \mathrm{Ca}^{2+}(20 \mu \mathrm{M})\end{array}$ \\
\hline Control & 19.8 \\
Botx A $70 \mathrm{nM}$ & 10.9 \\
$14 \mathrm{nM}$ & 17.6 \\
$2.8 \mathrm{nM}$ & 18.7 \\
\hline
\end{tabular}

$\left[{ }^{3} \mathrm{H}\right]$ Dopamine-preloaded cells were incubated with SLO at $0^{\circ} \mathrm{C}$ for $2 \mathrm{~min}$ [1]. The medium was replaced by fresh buffer supplemented with Botx A and $1 \mathrm{mM}$ DTT. After $20 \mathrm{~min}$ at $37^{\circ} \mathrm{C}$ the cells were stimulated with $20 \mu \mathrm{M}$ free $\mathrm{Ca}^{2+}$ for $10 \mathrm{~min}$. Values are means of two determinations. Release in the absence of $\mathrm{Ca}^{2+}(14 \%)$ was subtracted 


\section{DISCUSSION}

It has been recognized that Botx $\mathrm{A}$ as well as Tetx does not solely affect the secretory process of neurons. When applied extracellularly, Botx A, B and $D$, but not Tetx, inhibit exocytosis from chromaffin cells $[7,14]$. The sensitivity of adrenal chromaffin cells to Botx A can be increased by pretreating the cells with a ganglioside mixture which mimicks the ganglioside pattern of the neuronal plasma membrane. After this treatment, the cells even become sensitive to Tetx [15]. The difference in sensitivity between nerve cells [16] and pretreated [15] or untreated [7] adrenal chromaffin cells towards clostridial neurotoxins may be due to variations in the uptake of extracellularly applied neurotoxins by these cells.

When directly applied to the cytosol by injection [6] or through large pores in the plasma membrane $([1,2,8]$, this paper) both Tetx $[1,2,6,8]$ and Botx $A$ ([6], this paper) inhibit the $\mathrm{Ca}^{2+}$-stimulated exocytosis from chromaffin cells. Thus, Tetx and Botx A interfere with steps during exocytosis which are common to neurons and chromaffin cells and occur after the intracellular rise of $\mathrm{Ca}^{2+}$.

The intracellular actions of Botx A and Tetx are difficult to analyze when applied extracellularly or injected into single cells. SLO inserts defined pores large enough for the free passage of proteins into the plasma membrane $[17,18]$. In SLOpermeabilized adrenal medullary chromaffin or PC12 cells, the efficacy of Tetx $[1,2]$ and Botx A (this paper) can be compared more directly. The inhibitory action of Botx $\mathrm{A}$ is greatly augmented under reducing conditions, i.e. by addition of DTT. This indicates that the $\mathrm{S}-\mathrm{S}$ bond which links the heavy and the light chains must be broken before exocytosis can be inhibited. For Tetx the same holds true ([2], this paper) and, after chain separation, the light chain alone can inhibit exocytosis [1].

Besides the generally used 'two-chain' form, the clostridial neurotoxins also exist in a 'single-chain' form where the light and heavy chains are linked by a peptide bond in addition to the disulfide bond [3-5]. When subjected to SDS-PAGE under reducing conditions, these forms cannot be separated into a light and a heavy chain. Accordingly, even in the presence of DTT, singlechain Tetx does not inhibit exocytosis from per- meabilized chromaffin cells [1]. A preparation of Botx B, which proved to be in single-chain form when subjected to SDS-PAGE, similarly did not affect catecholamine release from permeabilized chromaffin cells (unpublished).

When applied extracellularly, the single-chain form of Botx B is also less effective as compared to the two-chain form in Aplysia neurons and mouse hemidiaphragm [19]. The same applies for the single-chain of Tetx when tested in primary cultures of mouse brain and in vivo [20].

At present, it is not known whether intracellularly applied Tetx light chain alone inhibits exocytosis from neurons as it does in permeabilized adrenal chromaffin cells [1]. In contrast, the light chain of Botx A, when injected into Aplysia neurons, has no effect. In these neurons both the heavy and the light chain of Botx A must be present to inhibit transmitter release [21]. Further experiments will show whether the light chain of Botx $\mathrm{A}$ alone or a combination of both heavy and light chains is responsible for the inhibition of exocytosis from chromaffin cells. It is also unclear whether the light chain of Tetx alone inhibit exocytosis when injected into neurons. Such experiments should provide further information as to whether Tetx and Botx A act via a different molecular mechanism. Otherwise different mechanisms of exocytosis must be assumed to operate in endocrine cells and neurons.

The pharmacological differences between the actions of Tetx and Botx A have been attributed to different plasma membrane receptors involved in the internalization of both toxins leading to the same intracellular action [22]. A similar molecular mechanism for the action of Tetx and Botx A within the cells has been predicted from their primary structure [23]. However, from studies using mouse hemidiaphragm, different effects of Tetx and Botx A have been deduced [24]. Experiments with permeabilized chromaffin cells support the latter conclusion: whereas Botx $\mathrm{A}$ gives rise to incomplete inhibition of $\mathrm{Ca}^{2+}$-stimulated exocytosis $([6,7]$, this paper) Tetx fully blocks this cellular response $([1,6,8]$, this paper). The observed differences in effective doses of Tetx and Botx A also constitute evidence against the assumption of a fully identical mechanism of intracellular action.

Clostridial neurotoxins will become valuable 
tools to define single steps of cellular pathways connecting the rise in intracellular $\mathrm{Ca}^{2+}$ concentration to fusion of the vesicular and plasma membrane. Such stepwise analysis may eventually lead to an understanding of the underlying molecular mechanisms.

Acknowledgements: We are indebted to Mrs M. Rudolf for skillful technical assistance, S. Bhakdi, E. Habermann and U. Weller, Giessen, for the supply of valuable toxins and K.-J. Föhr, Ulm, for his help in determination of free $\mathrm{Ca}^{2+}$ concentrations. This work was supported by the Deutsche Forschungsgemeinschaft and the State of Baden-Württemberg.

\section{REFERENCES}

[1] Ahnert-Hilger, G., Weller, U., Dauzenroth, M.-E., Habermann, E. and Gratzl, M. (1989) FEBS Lett. 242, 245-248.

[2] Ahnert-Hilger, G., Bader, M.-F., Bhakdi, S. and Gratzl, M. (1989) J. Neurochem. 52, 1751-1758.

[3] Habermann, E. and Dreyer, F. (1986) Curr. Top. Microbiol. Immunol. 129, 93-179.

[4] Sellin, L.C. (1987) Asia Pacific J. Pharmacol. 2, 203-222.

[5] Simpson, L.L. (1986) Annu. Rev. Pharmacol. Toxicol. 26, 427-453.

[6] Penner, R., Neher, E. and Dreyer, F. (1986) Nature 324, 76-78.

[7] Knight, D.E. (1986) FEBS Lett. 207, 222-226.

[8] Bittner, M.A. and Holz, R.W. (1988) J. Neurochem. 51, 451-456.
[9] Livett, B. (1984) Physiol. Rev. 64, 1103-1161.

[10] Ahnert-Hilger, G., Bhakdi, S. and Gratzl, M. (1985) J. Biol. Chem. 260, 12730-12734.

[11] Ahnert-Hilger, G., Mach, W., Föhr, K.-J. and Gratzl, M. (1989) Methods Cell Biol. 31, 63-90.

[12] Sillen, L. and Martell, A. (1971) The Chemical Society, London, suppl.1.

[13] Ammann, D., Bührer, T., Schefer, U., Müller, M. and Simon, W. (1987) Pflügers Arch. 409, 223-228.

[14] Knight, D.E., Tonge, D.A. and Baker, P.F. (1985) Nature 317, 719-721.

[15] Marxen, P., Fuhrmann, U. and Bigalke, H. (1989) Toxicon, in press.

[16] Habermann, E., Müller, H. and Hudel, M. (1988) J. Neurochem. 51, 522-527.

[17] Bhakdi, S., Tranum-Jensen, J. and Sziegoleit, A. (1985) Infect. Immun. 47, 52-60.

[18] Bhakdi, S. and Tranum-Jensen, J. (1987) Rev. Physiol. Biochem. Pharmacol. 107, 147-223.

[19] Maisey, E.A., Wadsworth, J.D.F., Poulain, B., Shone, C.C., Melling, J., Gibbs, P., Tauc, L. and Dolly, O. (1988) Eur. J. Biochem. 177, 683-691.

[20] Weller, U., Mauler, F. and Habermann, E. (1988) Naunyn-Schmiedeberg's Arch. Pharmacol. 338, 99-106.

[21] Poulain, B., Tauc, L., Maisey, E.A., Wadsworth, J.D.F., Mohan, P.M. and Dolly, J.O. (1988) Proc. Natl. Acad. Sci. USA 85, 4090-4094.

[22] Mellanby, J. (1984) Neuroscience 11, 29-34.

[23] Eisel, U., Jarausch, W., Goretzki, K., Henschen, A., Engels, J., Weller, U., Hudel, M., Habermann, E. and Niemann, H. (1986) EMBO J. 5, 2495-2502.

[24] Dreyer, F., Becker, C., Bigalke, H., Funk, H., Rosenberg, F. and Ziegler, M. (1984) J. Physiol. (Paris) 79, 252-258. 